JURNAL KETAHANAN NASIONAL

Vol. 24, No.1, April 2018, Hal 27-46

DOI:http://dx.doi.org/ 10.22146/jkn.30903

ISSN:0853-9340(Print), ISSN:2527-9688(Online)

Online sejak 28 Desember 2015 di :http://jurnal.ugm.ac.id/JKN

VOLUME 24

No. 1, April 2018

Halaman 27-46

\title{
Urgensi Kurikulum ASEAN Pada Pendidikan Bintara Polri Dalam Menanggulangi Kejahatan Transnasional Untuk Ketahanan Nasional
}

\author{
Joko Santoso, \\ Afilition: Fakultas Ilmu Sosial dan Ilmu Politik, Universitas Jenderal Soedirman \\ Email:mas_joko@ymail.com \\ Agus Haryanto, \\ Afilition:Fakultas Ilmu Sosial dan Ilmu Politik, Universitas Jenderal Soedirman \\ Email:agus.haryanto@unsoed.ac.id
}

Arief B. Darmawan

Afiliation:Fakultas Ilmu Sosial dan Ilmu Politik, Universitas Jenderal Soedirman

Email:arief.darmawan@unsoed.ac.id

\begin{abstract}
This research analyzed the importance of the subjects of the Association of Southeast Asian Nations (ASEAN) in the education curriculum for the Indonesian National Police (Polri). The Indonesian police was an important actor who had the functions and duties as protector of society. The community as police partners here was widely interpreted as an ASEAN society.

This study used qualitative methods that position researchers as an instrument to understood the problem. In this study, researchers took the meaning of the research object by using two kinds of sources. The first data sources were literature review and official documentation. The second data sources were interviews with police officers and police school staffs. For data validation, this research used data trangulation method.

This paper argued that the relations between police and the public should evolved to followed the emerging changes in contemporary international relations in Southeast Asia, so that the police education curriculum needed to adapted these developments. The changes in the curriculum were aimed at improving the quality and effectiveness of police tasks and functions. Thus, this study aimed to helped strengthen police institutions and built models that were in line with changes in society and international relations in Southeast Asia.
\end{abstract}

Keywords: Curriculum for Police Officer, Indonesian Police, ASEAN Community, National Resilience

\footnotetext{
ABSTRAK

Penelitian ini mengkaji mengenai pentingnya mata pelajaran Association of Southeast Asian Nations (ASEAN) dalam kurikulum pendidikan Bintara Kepolisian Negara Republik Indonesia (Polri). Penelitian ini berusaha menganalisis kepolisian Indonesia sebagai aktor penting yang memiliki fungsi dan tugas sebagai pengayom masyarakat. Masyarakat sebagai mitra kerja polisi di sini diartikan secara luas sebagai masyarakat ASEAN.

Penelitian ini menggunakan metode kualitatif yang menempatkan peneliti sebagai instrumen kunci dalam memahami masalah. Dalam penelitian ini, peneliti mengambil makna dari obyek penelitian dengan menggunakan dua sumber data. Sumber data pertama adalah studi pustaka literatur dan dokumentasi resmi. Sumber data kedua adalah wawancara dengan pejabat kepolisian dan staf pengajar sekolah polisi. Untuk validasi data, penelitian ini menggunakan metode trangulasi data.
} 
Argumen penelitian ini adalah relasi polisi dan masyarakat harus berkembang mengikuti perubahan yang muncul dalam hubungan internasional kontemporer di kawasan Asia Tenggara, sehingga kurikulum pendidikan polisi perlu menyesuaikan perkembangan tersebut. Perubahan kurikulum pendidikan tersebut ditujukan untuk meningkatkan kualitas dan efektivitas tugas dan fungsi kepolisian. Dengan demikian, penelitian ini bertujuan membantu penguatan kelembagaan kepolisian dan membangun model yang sesuai dengan perubahan masyarakat dan hubungan internasional di kawasan Asia Tenggara.

\section{Kata kunci: Kurikulum Pendidikan Bintara, Polri, Masyarakat ASEAN, Ketahanan Nasional}

\section{PENGANTAR}

Tugas dan fungsi kepolisian tidak bisa dilepaskan dari keberadaan masyarakat. Selama ini, polisi telah dianggap sebagai pengayom masyarakat. Masyarakat memandang bahwa dengan keterampilan dan keunggulan pengetahuannya, polisi merupakan institusi yang memiliki kemampuan dalam menghadapi dan mengelola situasi di lingkungannya supaya tidak mengarah kepada adanya tindak kejahatan. Selain dari sisi pencegahan, polisi juga diharapkan mampu untuk menyelesaikan persoalan kriminal yang muncul di tengah masyarakat, seperti pencurian, kehilangan anak atau barang, pelanggaran lalu lintas, serta hal-hal lainnya. Untuk mendukung menjalankan tugas dan fungsi tersebut, polisi harus dapat memahami karakteristik masyarakat dan infrastruktur jaringan kontrol sosial yang merupakan prioritas untuk terbangunnya strategi menjaga ketertiban yang sesuai dengan komunitas di sekitarnya (Alpert, dkk, 2000: 408). Strategi menjaga ketertiban di suatu wilayah belum tentu solusi yang sesuai dan cocok dengan wilayah yang lain (Ibarra, 2003: 159).

Namun dalam beberapa tahun terakhir muncul situasi baru dalam masyarakat. Globalisasi telah membuat sekat-sekat batas negara menjadi lebih cair dan membuat perpindahan manusia semakin mudah. Masyarakat tidak lagi terdiri dari masyarakat yang homogen. Di lingkungan regional, warga dari negara Asia Tenggara lainnya bisa lebih mudah memasuki dan tinggal di Indonesia daripada sebelumnya. Hal ini diikuti dengan kebijakan-kebijakan di antara para pemimpin ASEAN mengenai kemudahan transportasi antarnegara ASEAN, liberalisasi perdagangan dalam rangka integrasi ekonomi, dan ke depan mengenai liberalisasi bidang jasa. Artinya, warga negara Thailand, Laos, atau Filipina, misalnya, dapat menjalankan bisnis dan bekerja di seluruh wilayah Indonesia, termasuk daerah-daerah kota menengah dan kota kecil seperti Purwokerto, Cirebon, dan kota lainnya.

Untuk itu yang perlu dipikirkan oleh kalangan kepolisian adalah bagaimana membawa pengetahuan ASEAN ke dalam kurikulum pendidikan dan pelatihan Polri. Hal ini sangat penting untuk menumbuhkan pemahaman dan wawasan ASEAN dalam menangani praktek-praktek di lapangan. Ke depan, munculnya warga negara lain bisa berimplikasi pada ketertiban di masyarakat. Masyarakat yang heterogen, yang tidak hanya berbeda negara, namun juga berbeda bahasa, budaya, dan pemahaman aturan di suatu negara, akan berimplikasi dengan kemampuan kepolisian dalam mengatasi persoalan yang mungkin muncul.

Polri merupakan salah satu penyokong dalam asas keamanan dan ketertiban masyarakat. Sesuai dengan UU Nomor 2 tahun 2002 tentang Polri disebutkan keamanan dan ketertiban masyarakat dimaknai sebagai suatu kondisi dinamis masyarakat sebagai salah satu prasyarat terselenggaranya proses 
pembangunan nasional dalam rangka tercapainya tujuan nasional yang ditandai oleh terjaminnya keamanan, ketertiban dan tegaknya hukum, serta terbinanya ketentraman yang mengandung kemampuan membina serta mengembangkan potensi dan kekuatan masyarakat dalam menangkal, mencegah dan menanggulangi segala bentuk pelanggaran hukum dan bentuk-bentuk gangguan lainya yang dapat meresahkan masyarakat.

Kepolisian RI merupakan alat negara yang menurut UU No. 2 Tahun 2002 pasal 5 dan pasal 13 berperan dan bertugas dalam memelihara keamanan dan ketertiban masyarakat, menegakkan hukum, dan memberikan perlindungan, pengayoman, dan pelayanan kepada masyarakat, demi keamanan dalam negeri. Bersamaan dengan peran dan tugas tersebut, fungsi kepolisian sesuai dengan yang disebutkan dalam pasal 2 adalah salah satu fungsi pemerintahan negara di bidang pemeliharaan keamanan dan ketertiban masyarakat, penegakan hukum, perlindungan, pengayoman, dan pelayanan kepada masyarakat.

Fungsi polisi tumbuh dan berkembang bersamaan dengan adanya keinginan masyarakat untuk selalu merasa aman dan tentram (Kunarto, 1997: 45). Polisi modern yang dikenal pada masa ini merupakan polisi model masyarakat Inggris pada abad 19 yang memiliki karakteristik yang berbeda dari abad sebelumnya (Bittner, 1970 : 15). Pada saat itu, secara umum, masyarakat Inggris mulai berkembang menjadi masyarakat urbanindustri. Polisi modern baru terbentuk setelah adanya organ administrasi yang mengurusi hal lain seperti wajib militer, penarikan pajak, rencana ekonomi dan keuangan, serta pelayanan sosial. Bittner (1970: 16) menjelaskan bahwa fakta tersebut tidak bisa lepas dari angka kriminalitas yang meningkat pesat pada awal tahun 1800-an, khususnya pada tahun 1820-an ketika masyarakat London mengalami kejahatan kriminal yang sangat brutal. Metode menjaga ketertiban masyarakat pada saat itu dirasa tidak mampu lagi untuk mengatasi persoalan yang ada. Penggunaan represi bersenjata tetap tidak dapat mencegah dan mengatasi persoalan. Bersamaan dengan itu, mulai muncul opini di masyarakat barat untuk menghilangkan kekerasan dan menekankan perdamaian dalam kehidupan sehari-hari (Bittner, 1970: 17).

Meskipun kekerasan (termasuk, misalnya, peperangan) tetap tidak dapat dimusnahkan dari generasi ke generasi, setidaknya mulai tahun 1900-an secara progresif tumbuh opini hampir di seluruh masyarakat di Eropa bahwa generasi modern tidak dapat lagi menjustifikasi kekerasan sebagai sesuatu yang diperbolehkan. Pedang, pisau, atau senapan bukan lagi merupakan alat yang diperlukan untuk menangani masalah dengan orang lain. Ada pergeseran nilai yang mana masyarakat lebih menekankan pada kemajuan ekonomi dan tumbuhnya iklim usaha yang ditopang oleh perdamaian. Nilai-nilai kebebasan dan jauh dari kekerasan merupakan nilai baru dalam masyarakat. Dua perkembangan yang perlu dicatat dari situ adalah (1). Kepatuhan terhadap ototitas politik tidak terlalu tergantung pada kehadiran pegawai negara dan praktek pemaksaan secara fisik, melainkan pada kesadaran masing-masing warga negara. (2). Penggunaan kekerasaan dalam metode hukum atas kriminal mulai berkurang. Metode hukuman dalam pengadilan modern mulai beranjak pada, misalnya, dorongan untuk melakukan rehabilitasi.

Sementara itu, ada perkembangan baru dalam ranah studi keamanan sejak awal tahun 1990-an (Caballero-Anthon, 2006: 1). Istilah 
keamanan menjadi tema yang diperdebatkan. Para akademisi dan pemerhati studi ini mulai mempertanyaan definisi konvensional. Definisi keamanan tradisional yang terbatas pada dimensi militer dalam relasi antarnegara menjadi obyek yang dipertanyakan. Definisi tersebut tidak lagi sesuai dengan perkembangan global karena obyek keamanan pada masa kini tidak terbatas pada negara dan pertahanan terhadap serangan ancaman militer negara lain. Keamanan tidak lagi didominasi masalah militer dan negara, tapi juga masalah non-militer, seperti lingkungan dan masyarakat. Isu-isu seperti penyakit menular, perdagangan ilegal narkoba, penyelundupan dan perdagangan manusia, serta degradasi kerusakan lingkungan menjadi fokus penting yang berimplikasi pada keamanan. Dalam literatur studi keamanan, perhatian terhadap ancaman-ancaman non-militer tersebut masuk dalam kategori keamanan non-tradisional.

Lembaga seperti Consortium of Non-Traditional Security Studies in Asia (NTS-Asia) mendefinisikan keamanan nontradisional sebagai

"challenges to the survival and wellbeing of peoples and states that arise primarily out of non-military sources, such as climate change, infectius diseases, natural disasters, irregular migration, food shortages, smuggling of persons, drug trafficking and other forms of transnational crime" (Caballero-Anthony, 2010).

Definisi tersebut menunjukkan bahwa keamanan non-tradisional memiliki jangkauan yang dalam dan luas. Caballero-Anthony (2010) mencontohkan wabah SARS (severe acute respiratory syndrome) yang melanda kawasan Asia pada tahun 2003. Dalam isu ini, globalisasi memainkan peran penting. Globalisasi membuat kekhawatiran bahwa wabah SARS akan menyebar sangat luas dengan adanya kemudahan perpindahan manusia. Orang yang terkena wabah ini berpotensi menimbulkan ancaman terhadap keamanan masyarakat dimana pun berada. Namun, tidak hanya itu. SARS juga mengakibatkan kerugian yang besar secara ekonomi. Menurut estimasi, kerugian akibat SARS di Asia Tenggara dan Asia Timur sebesar \$18-60 juta, yang berasal dari pengeluaran langsung, kerugian bisnis dan pariwisata, serta melambatnya kemajuan ekonomi (Fischer, 2008: 251).

Sebagaimana yang terjadi pada ancaman wabah SARS tahun 2003, menurut CaballeroAnthony (2010: 1), keamanan non-tradisional memiliki kerakteristik umum sebagai berikut: (1). Terkait isu non-militer; (2). Berada dalam lingkup lintas negara; (3). Muncul dalam waktu singkat dan menyebar dengan cepat sebagai hasil dari globalisasi dan revolusi komunikasi; (4). Tidak bisa dicegah sepenuhnya, tapi bisa dikurangi melalui mekanisme penanggulangan; (5). Solusi domestik seringkali tidak cukup mampu mengatasi, sehingga kerja sama regional dan multilateral sangat dibutuhkan; dan (6). Tujuan keamanan tidak lagi negara seperti kedaulatan atau teritorial, namun juga manusia baik individu maupun masyarakat.

Berdasarkan definisi dan karakteristik tersebut, keamanan non-tradisional sangat dekat dengan penanggulangan terhadap kejahatan transnasional. Kejahatan transnasional ini tidak secara langsung memberi ancaman terhadap kedaulatan teritorial, namun lebih merupakan tantangan terhadap pemerintahan yang efektif(Anggoro, 2003: 25). Oleh karena itu, pemerintah melalui lembaga atau institusi yang terkait harus secara cepat melibatkan diri dalam penanganan secara regional dan global. Lingkup batas negara dalam menghadapi 
tantangan keamanan non-tradisonal tidak bisa lagi dihadapi menggunakan kebijakan dan ukuran-ukuran domestik. Sebagai hasil dari pemahaman itu, di kawasan Asia Tenggara juga mulai muncul pengakuan bahwa kawasan ini membutuhkan pendekatan regional dan memecahkan tantangan-tantangan keamanan masa kini (Caballero-Anthony, 2010: 2). Pada tahun 1997, para kepala negara anggota ASEAN telah menandatangani dokumen Visi 2020 yang di antaranya berisi aturanaturan berperilaku dan tindakan kerjasama dalam menghadapi masalah yang berada dalam lingkup regional, termasuk kejahatan transnasional (Pushpanathan, 1999). Dua puluh tahun kemudian, ASEAN mengadopsi ASEAN Plan of Action in Combating Transnational Crime sebagai kontribusi realisasi $A S E A N$ Political-Security Community Blueprint 2025 (ASEAN, 2017).

Dengan memahami sejarah dan perkembangan tersebut, polisi harus memahami perkembangan yang terjadi, baik pada lingkup masyarakat domestik maupun wawasan regional. Polisi juga harus menangani tindakan pelanggaran dengan tegas serta memberikan perlindungan yang berkaitan dengan upaya-upaya pencegahan terjadinya pelanggaran atau tindakan yang menganggu keamanan dan ketertiban, termasuk gangguan keamanan non-tradisonal yang berkaitan dengan kejahatan transnasional. Dalam menangani persoalan keamanan dan ketertiban masyarakat tersebut, sesuai dengan UndangUndang Nomor 34 tahun 2004 tentang Tentara Nasional Indonesia (TNI), kepolisian mendapatkan bantuan TNI (Hediarto, Armawi, \& Martono 2016: 326). Tentara Nasional Indonesia (TNI), menurut UU No. 34 Tahun 2004 pasal 6, berfungsi sebagai komponen utama sistem pertahanan negara untuk menangkal setiap bentuk ancaman militer dan ancaman bersenjata dari luar dan dalam negeri terhadap kedaulatan, keutuhan wilayah, dan keselamatan bangsa, menindak setiap bentuk ancaman, dan memulihkan kondisi keamanan negara yang terganggung akibat kekacauan keamanan. Namun, TNI juga bertugas dalam operasi militer selain perang, seperti mengatasi aksi terorisme maupun mengamankan wilayah perbatasan. Dengan demikian, polisi dan TNI bergerak secara efektif dalam bidang jangkauan yang luas menurut perundang-undangan yang berlaku.

Dengan mengamati tugas kepolisian serta hubungannya dengan masyarakat, dapat dikatakan bahwa polisi dan masyarakat memiliki relasi saling ketergantungan. Oleh karena itu, perkembangan apapun yang terjadi di tengah masyarakat di masa depan memerlukan perhatian dan kehadiran kepolisian, sehingga ketertiban dan keamanan di masyarakat bisa terwujud. Selama ini, kajian mengenapi kepolisian sangat terbatas pada permasalahan domestik. Danendra (2012) dalam tulisannya berjudul Kedudukan dan Fungsi Kepolisian dalam Struktur Organisasi Negara Republik Indonesia hanya membahas mengenai peran lembaga kepolisian untuk memelihara keamanan dan ketertiban masyarakat dalam negeri. Merianingrum (2014), dalam tulisan Peranan Kemitraan Polisi Republik Indonesia dalam Memelihara Stabilitas Keamanan dan Ketertiban Masyarakat membahas mengenai kemitraan polisi dan masyarakat setempat. Sementara itu, Rusdi (2014) membahas mengenai peran kepolisian dalam menanggulangi tindak pidana pelaporan palsu kehilangan sepeda motor.

Berbeda dengan kajian-kajian sebelumnya, dalam artikel ini peneliti 
Tabel 1

Kurikulum Bintara Polri Tugas Umum 2017

\begin{tabular}{|c|c|c|}
\hline No. & Kategori & Mata Pelajaran \\
\hline I & Pengantar & $\begin{array}{l}\text { A. Pengenalan Lingkungan \& Tradisi Lembaga Pendidikan } \\
\text { B. Pengarahan Program } \\
\text { 1. Jam Pimpinan; } \\
\text { 2. Pola Kurikulum \& Sistem Evaluasi; } \\
\text { 3. Perdupsis \& Pola Pengasuhan. } \\
\text { C. Tes Kesehatan dan Kesamaptaan Jasmani }\end{array}$ \\
\hline II & $\begin{array}{l}\text { Kelompok Mata } \\
\text { Pelajaran }\end{array}$ & $\begin{array}{l}\text { A. Kepribadian } \\
\text { 1. Revolusi Mental (Perubahan Mindset \&Culture Set Polri); } \\
\text { 2. Kode Etik Profesi Polri dan Tata Krama/ Etika; } \\
\text { B. Pengetahuan Sosial } \\
\text { 3. Sejarah Juang Polri; } \\
\text { 4. Bela Negara; } \\
\text { 5. Kerukunan Hidup Umat Beragama; } \\
\text { 6. Pelayanan Prima; } \\
\text { 7. Pengantar Manajemen Intelijen Muda; } \\
\text { C. Hukum } \\
\text { 8. UU No. } 2 \text { Tahun } 2002 \text { tentang Kepolisian Negara RI } \\
\text { 9. KUHP; } \\
\text { 10. KUHAP; } \\
\text { 11. Kapita Selekta Perundang-undangan; } \\
\text { 12. Peraturan Pemberhentian, Disiplin, Tata Cara Peradilan Umum bagi } \\
\text { Anggota Polri } \\
\text { D. Profesi Teknis Kepolisian } \\
\text { 13. Hak Asasi Manusia dan Gender; } \\
\text { 14. FT Sabhara } \\
\text { 15. Tindakan Pertama Tempat Kejadian Perkara; } \\
\text { 16. Tipiring; } \\
\text { 17. Laporan Polisi dan Berita Acara; } \\
\text { 18. Dalmas; } \\
\text { 19. Bantuan SAR dan PPGD; } \\
\text { 20. Psikologi Massa dan Negosiasi; } \\
\text { 21. Fungsi Teknis Lalu Lintas; } \\
\text { 22. Fungsi Teknis Intelkam; } \\
\text { 23. Fungsi Teknis Reserse; } \\
\text { 24. Fungsi Teknis Binmas; } \\
\text { 25. Hakikat Gangguan Kamtibnas; } \\
\text { 26. Polmas; } \\
\text { 27. Pelayanan Perempuan dan Anak dan Penanganan } \\
\text { 28. Anak yang Berhadapan dengan Hukum } \\
\text { 29. Penggunaan Kekuatan dalam Tindakan Kepolisian; } \\
\text { 30. Komunitas Elektronik Polri; } \\
\text { 31. Organisasi Polri; } \\
\text { 32. Administrasi Umum Polri } \\
\text { Jasmani } \\
\text { 33. Persenjataan dan Menembak; } \\
\text { 34. Beladiri Polri } \\
\text { 35. Peraturan Dasar Kepolisian. } \\
\text { 19and }\end{array}$ \\
\hline III & Pembulatan & $\begin{array}{l}\text { A. Tutup Dashbara (Outbond); } \\
\text { B. Latihan Teknis; } \\
\text { C. Latihan Kerja; } \\
\text { D. Pembekana (Ceramah); }\end{array}$ \\
\hline IV & Kegiatan Lain-lain & $\begin{array}{l}\text { A. Implementasi Karakter Kebhayangkaraan dan Kepribadian Bangsa } \\
\text { (Revolusi Mental) } \\
\text { B. Implementasi Pendidikan Budaya Anti Korupsi } \\
\text { C. Buka/ Tutup Pendidikan }\end{array}$ \\
\hline
\end{tabular}


ingin membangun kesiapan polisi dalam menghadapi era tantangan global, dimulai dengan penyusunan kurikulum yang memadai.

Untuk menunjang hal tersebut, penelitian ini menggunakan metode kualitatif yang menempatkan peneliti sebagai instrumen kunci dalam memahami masalah (Creswell, 2010). Dalam penelitian ini, peneliti mengambil makna dari obyek penelitian dengan menggunakan dua sumber data. Sumber data pertama adalah studi pustaka literatur dan dokumentasi resmi. Dalam penelitian ini, peneliti membaca dokumen resmi pemerintah seperti peraturan, kurikulum, dan laporan lembaga. Sementara itu, pustaka literatur diperoleh melalui jurnal dan laporan lembaga non pemerintah. Sumber data kedua adalah wawancara dengan pejabat kepolisian dan staf pengajar sekolah polisi. Dalam hal ini, peneliti melakukan wawancara dengan sejumlah polisi seperti Kapolsek dan staf pengajar di Sekolah Polisi Negara.

\section{PEMBAHASAN}

\section{Kurikulum Bintara Polri}

Pada bagian ini, peneliti mengamati Kurikulum Bintara Polri sesuai Surat Keputusan Kepala Lembaga Pendidikan dan Pelatihan Polri Nomor Kep/ 252/V/2017 tentang Pendidikan Pembentukan Bintara Polri Tugas Umum. Bintara adalah pangkat kepolisian yang berada di bawah kelompok Bintara Tinggi dan di atas kelompok Tamtama. Bintara Polri merupakan pelayan masyarakat terdepan dari Kepolisian Republik Indonesia, yang berada pada tataran operasional. Untuk menjadi Bintara, hanya ada satu jalur yang harus ditempuh, yaitu melalui Sekolah Polisi Negara (SPN). Pendidikan Bintara Polri berlangsung selama 7 bulan, yang dibagi menjadi tiga pola pendidikan, yaitu 2 bulan untuk pembentukan dasar Bhayangkara, 4,5 bulan untuk pembekalan profesi kepolisian, serta 0,5 bulan untuk pembulatan yang meliputi latihan teknis, latihan kerja, dan pembekalan. Pentahapan kurikulum Bintara Polri mengikuti pola pendidikan (Lembaga Pendidikan dan Pelatihan Markas Besar Polri, 2017: 2). Tahap pembentukan Bhayangkara adalah tahap penanaman nilai-nilai luhur dan karakter. Tahap pembekalan profesi Kepolisian adalah tahap pemberian pengetahuan, keterampilan teknik dan taktik tugas umum. Tahap pembulatan adalah tahap pemberian pengalaman belajar, baik dalam bentuk latihan teknis, latihan kerja, maupun ceramah.

Kurikulum tersebut bertujuan untuk menghasilkan Bintara Polri sebagai Insan Bhayangkara yang memiliki sikap perilaku, pengetahuan, keterampilan tugas umum Kepolisian, didukung dengan kondisi fisik yang samapta untuk melaksanakan tugas sebagai pemelihara kamtibmas, penegak hukum, pelindung, pengayom, dan pelayan masyarakat yang profesional, bermoral, modern dan unggul (lihat tabel 1) (Lembaga Pendidikan dan Pelatihan Markas Besar Polri, 2017: 1).

Jika membaca silabus Bintara Polri, akan terlihat bahwa apa yang dipelajari di kepolisian memiliki lingkup yang cukup luas. Materi yang diajarkan mulai dari revolusi mental, semangat juang Polri dalam berbagai zaman sebelum dan sesudah kemerdekaan, sampai pada poros maritim dalam mata pelajaran bela negara. Dalam revolusi mental, Bintara Polri diharapkan untuk memahami dan terampil dalam menerapkan pola sikap dan karakter Polri yang berkepribadian bangsa. Di antara karakter tersebut adalah perubahan pola pikir dan kultur, mempelajari ketrampilan 
dasar perorangan dan kepemimpinan tingkat dasar dalam kehidupan sehari-hari seperti ketrampilan mengamati atau umpan balik, serta menerapkan nilai-nilai revolusi mental seperti integritas, etos kerja, gotong royong, serta sikap saling menghargai. Dalam mempelajari sejarah juang Polri, para bintara diharapkan untuk memahami nilai-nilai sejarah perjuangan Polri untuk menumbuhkan jiwa kejuangan. Sejarahsejarah yang dipelajari meliputi sejarah sejak era Majapahit, era Belanda, era penumpasan gerakan-gerakan pemberontakan seperti APRA (Angkatan Perang Ratu Adil), RMS (Republik Maluku Selatan), DI/ TII, serta sejarah-sejarah Polri pada masa Orde Baru, Orde Reformasi, dan sejarah pahlawan nasional Moehammad Djasin. Dalam mata pelajaran bela negara, Bintara Polri diharapkan memiliki kemampuan untuk menjelaskan pengertian negara serta ketahanan nasional dan keamanan dalam negeri. Memahami hakikat cinta tanah air dan menjelaskan mengenai poros maritim serta arti penting Indonesia sebagai negara maritim juga merupakan indikator hasil belajar Bintara Polri untuk mata pelajaran bela negara. Kerukunan beragama juga menjadi isu penting yang secara khusus dipelajari oleh polisi, mengingat bahwa Indonesia terdiri dari beragam agama dan keyakinan. Hal ini masih ditambah dengan tujuan Indonesia untuk menjadi destinasi favorit para turis mancanegara yang memiliki agama dan keyakinan yang makin beragam. Oleh karena itu, pelayanan prima dari polisi kepada masyarakat tidak luput dari mata pelajaran yang harus ditekuni oleh Bintara Polri. Selain di bidang kepribadian dan pengetahuan sosial, Bintara Polri juga dibekali dengan pengetahuan di bidang hukum, bidang teknis, bidang jasmani, serta pendidikan budaya antikorupsi.

Dari banyak standar kompetensi dan kompetensi dasar yang digagas Polri untuk Bintara, terdapat setidaknya tiga materi yang berkaitan dengan konteks internasional kontemporer, yaitu materi-materi yang berkaitan dengan penanganan narkotika, psikotropika, dan isu-isu terorisme; peranan hak asasi manusia dalam kerja kepolisian; dan materi-materi mengenai prosedur tindak pidana ringan dan penyelidikan tindak pidana atau ketrampilan negosiasi yang mungkin saja bisa melibatkan warga negara asing. Secara lebih lengkap, hal tersebut diuraikan di bawah ini.

Pertama, materi seperti narkotika, psikotropika, dan terorisme yang memiliki irisan dengan kejahatan transnasional dipelajari dalam silabus Kapita Selekta Perundangundangan. Dalam masalah perdagangan gelap narkoba, Indonesia merupakan negara yang terletak pada jalur strategis. Letak yang strategis tersebut, selain menguntungkan, juga membuat Indonesia menjadi negara yang rentan terhadap perdagangan gelap dan penyebaran narkoba. Di kawasan Asia Tenggara, wilayah The Golden Triangle merupakan pusat produksi narkotika, heroin, dan amphetamine. Wilayah tersebut meliputi daerah Thailand bagian utara, Laos bagian barat, dan Myanmar bagian timur. Dari situ, penyebaran dan perdagangan gelap narkoba menyebar ke segala penjuru, termasuk Indonesia. Menurut laporan United Nations Office on Drugs and Crime (UNODC), meskipun Emmers (2007: 510) mengatakan cukup sulit untuk memperoleh data estimasi yang tepat mengenai jumah peredaran narkoba, nilai perdagangan heroin dan methamphetamin di Asia Tenggara pada tahun 
2013 diperkirakan sebesar 31 miliar dollar AS (Marshall, 2016). Salah satu faktor yang menunjang hal tersebut adalah globalisasi. Dalam globalisasi, sistem informasi dan teknologi yang semakin maju merupakan kunci penting. Dengan hal itu, era globalisasi adalah era mempermudah satu orang atau barang untuk berpindah dari satu negara ke negara lain. Hal itu turut mempermudah penyebaran dan perdagangan gelap narkoba, di mana sindikat pengedar narkotika lintas negara dapat menggunakan teknologi internet dan media sosial untuk berhubungdan dengan sindikat atau klien dagangnya di negara lain. Bahkan, perdagangan gelap narkotika tidak hanya menggunakan jalur darat saja, melainkan juga menggunakan jalur laut dan udara. Di sisi lain, aparat penegak hukum masih sulit untuk mendeteksi perdagangan atau transaksi gelap.

Menurut Badan Narkotika Nasional (BNN), sejak tahun 2008, perdagangan dan penyebaran gelap narkoba telah mencapai ke seluruh kabupaten di 33 provinsi di Indonesia. Hal tersebut menunjukkan bahwa tingkat penyebaran narkoba telah menjerat seluruh daerah di Indonesia. Dalam perdagangan gelap tersebut, total kerugian negara akibat penyalahgunaan narkoba mencapai kurang lebih 57 triliun rupiah. Laporan lain juga menyebutkan bahwa korban penyalahgunaan narkoba berjumlah 4 juta orang di Indonesia (BNN, 2013). Presiden-presiden Indonesia dari tahun ke tahun terus menekankan hal ini. Presiden Indonesia ke-5 Susilo Bambang Yudhoyono, misalnya, dalam pidato kenegaraan pada tahun 2013 menyebutkan bahwa Indonesia harus melakukan upaya yang konsisten dalam menangani kejahatan transnasional yang terus meningkat, termasuk di dalamnya "pemberantasan penyalahgunaan dan peredaran gelap narkoba" (BNN, 2013). Penekanan mengenai bahaya perdagangan, penyebaran, dan penggunaan narkoba juga dilakukan oleh Presiden Indonesia ke-6 Joko Widodo. Pada pidato Peringatan Hari Anti Narkotika Internasional di Istana Negara, tanggal 26 Juni 2015, Presiden Joko Widodo mengatakan bahwa penyalahgunaan narkoba memiliki kekuatan yang merusak. Dalam jangka panjang, penyalahgunaan narkoba akan berefek besar dan berpotensi besar menganggu daya saing dan kemajuan bangsa (Setkab, 2015). Ketika seorang anak Indonesia menggunakan narkoba, maka anak tersebut akan kehilangan kesadaran dan pada akhirnya kehilangan kemampuan untuk berprestasi. Dalam pidatonya, Presiden Joko Widodo menyatakan bahwa pengguna narkoba di Indonesia telah mencapai 4,1 juta orang, yaitu 2,2 persen dari total populasi. Dari jumlah pemakai sebanyak itu, penyalahgunaan narkoba mengakibatkan kerugian yang tidak sedikit bagi negara, yaitu lebih kurang 63 triliun rupiah. Hal ini memperlihatkan bahwa materi narkoba dan psikotropika merupakan materi yang relevan untuk dicegah dan ditumpas oleh pihak kepolisian. Untuk mencegah dan menumpas penyalahgunaan tersebut, kepolisian harus memiliki pengetahuan mengenai perkembangan dunia internasional kontemporer karena sumber dari masalah tersebut tidak hanya berada di Indonesia saja, melainkan melibatkan sindikat-sindikat dan jalur-jalur internasional. Seperti yang dikatakan Presiden Joko Widodo, kejahatan narkoba merupakan kejahatan yang bersifat lintas negara dan terorganisasi.

Terorisme juga merupakan isu yang menjadi masalah di Indonesia. Dalam beberapa tahun terakhir semenjak Peristiwa 11 September di Amerika Serikat, aksi-aksi 
terorisme di beberapa wilayah di Indonesia semakin meningkat. Menurut penelitian yang dilakukan oleh Purwawidada (2014: 6), misalnya, aksi terorisme di wilayah Solo dari tahun 2008 sampai 2012 memperlihatkan intensitas yang cenderung meningkat, yaitu dari 1 kasus pada tahun 2008, kemudian meningkat ke 3 kasus pada 2009, 6 kasus pada 2010, 4 kasus pada 2011, dan 18 kasus pada 2012. Pemikiran-pemikiran mengenai terorisme tersebut merupakan pengaruh dari ide-ide radikalisme yang berasal dari negara lain, yang kemudian dibawa ke Indonesia sebagai bentuk ketidakpuasan terhadap pemerintah yang tengah berkuasa. Kejahatan-kejahatan yang diakibatkan oleh isu transnasional itu, dalam kasus Indonesia, masih ditambah lagi dengan masalah-masalah di kawasan perbatasan yang selama ini cenderung kurang perhatian dari pemerintah pusat maupun daerah (Latif \& Agustan, 2017: 264). Wilayah perbatasan menjadi wilayah yang termaginalkan. Selain berefek pada kurangnya kesejahteraan kehidupan masyarakat yang tidak adil dan merata di seluruh Indonesia, wilayah perbatasan menjadi identik dengan ketidakjelasan pengelolaan. Menurut Latif dan Agustan (2017: 265-266), lembaga-lembaga yang memiliki kewenangan dalam menjaga perbatasan, seperti otoritas kepabeanan, imigrasi, karantina, dan keamanan, cenderung kurang terintegrasi. Ada tumpang tindih pengelolaan di sana. Efeknya, masalah yang muncul bisa tidak tertangani dengan baik, sehingga intensitas ancaman semakin bertambah. Padahal, penguasaan yang efektif akan daerah perbatasan merupakan hal yang signifikan dalam mencegah ancaman terhadap eksistensi kedaulatan dan pembangunan wilayah suatu negara. Persoalan internal itu masih ditambah lagi dengan persoalan eksternal yang berhubungan dengan negara lain. Dengan demikian, isu terorisme juga berkaitan dengan kejahatan transnasional lain seperti kejahatan perdagangan dan penyalahgunaan narkoba.

Kedua, kurikulum Bintara Polri juga memasukkan prinsip-prinsip dasar dan peranan HAM dalam pelaksanaan kerja kepolisian menurut standar internasional. Hak asasi manusia meliputi bagaimana manusia atau masyarakat mendapatkan perlindungan dari kekuasaan dan kekuatan negara, dan bagaimana hak asasi manusia menjadi jalan untuk membatasi kekuatan atau kekuasaan yang mengancam warga negara (SEAHRN, 2016: 2). Tema seputar hak asasi manusia memiliki lingkup yang luas, yaitu hak asasi perempuan, hak asasi anak, hak asasi seks dan gender, serta relasi hak asasi manusia dengan pembangunan, bisnis, lingkungan, media, dan hak berpolitik. Di kawasan Asia Tenggara, hak asasi manusia mulai mendapatkan tempat pada tahun 1970-an, bersamaan dengan tumubuhnya gerakan masyarakat sipil yang diinisiasi oleh gerakan mahasiswa maupun gerakan wanita. Pada tahun 1973 di Thailand, muncul gerakan pelajar/mahasiswa yang menuntut kebebasan dan demokrasi. Gerakan tersebut berhasil menumbangkan pemerintahan militer. Pada tahun 1988, muncul gerakan mahasiswa serupa di Myanmar, yang kemudian mendapatkan represi dari pihak militer. Hal yang sama pernah terjadi di Indonesia pada akhir masa pemerintahan Presiden Soeharto pada tahun 1998 (SEAHRN, 2016: 19-20).

Di Indonesia, beberapa persoalan hak asasi manusia masih menjadi pokok persoalan utama. Menurut Human Right Watch (2017), terkait hak asasi manusia, Indonesia masih mengalami masalah dalam isu kebebasan beragama, hak asasi 
perempuan, isu Papua, identitas gender dan orientasi seksual, hak asasi anak, serta soal pengungsi dan pencari suaka. Pada tahun 2016, misalnya, pemerintah dianggap gagal melindungi hak-hak 7000 anggota Gerakan Fajar Nusantara (Gafatar) di Kalimantan. Dalam peristiwa itu, penduduk lokal Melayu dan Dayak merusak properti dan rumah milik anggota Gafatar yang kebanyakan berasal dari Jawa. Pada bulan Januari 2016, pemerintah juga memiliki persoalan dengan komunitas Ahmadiyah di Sukabumi, Jawa Barat. Dalam isu hak asasi perempuan, Human Right Watch (2017) mencatat bahwa masih terdapat 422 regulasi pemerintah pusat dan daerah yang berindikasi diskriminasi terhadap perempuan. Dalam isu pengungsi dan pencari suaka, Perserikatan Bangsabangasa (PBB) mencatat ada sekitar hampir 14.000 pencari suaka di Indonesia pada tahun 2016. Hal tersebut menjadi sulit karena Indonesia bukan merupakan anggota Konvensi Pengungsi PBB dan tidak memiliki undang-undang yang lengkap mengenai pengungsi dan pencari suaka. Pada masa kini, persoalan hak asasi manusia tidak hanya menjadi perhatian negara atau individu, melainkan juga kelompok-kelompok nonpemerintah yang semakin tumbuh dalam kehidupan bernegara. Organisasi-organisasi non-pemerintah tersebut, baik organisasi lokal maupun internasional, dalam levellevel tertentu, bahkan memiliki pengaruh yang kuat dan sanggup menekan kebijakankebijakan pemerintah yang tidak sesuai dengan prinsip-prinsip hak asasi manusia yang mereka pahami. Dengan mengamati kasus-kasus tersebut, persoalan hak asasi manusia merupakan kasus yang relevan di masyarakat, dan bahkan mendapatkan perhatian dari masyarakat internasional.
Ketiga, kurikulum Bintara Polisi memasukkan materi yang dalam beberapa tahun akan semakin penting di masyarakat yang heterogen, seperti prosedur tindak pidana ringan dan penyelidikan tindak pidana terhadap kasus-kasus yang dilakukan oleh warga negara asing atau ketrampilan negosiasi dalam mata pelajaran psikologi massa dan negosiasi yang membutuhkan keterampilan berbahasa asing. Dengan semakin banyaknya warga negara asing yang masuk ke Indonesia, ditambah dengan semakin mudahnya peraturan yang memungkinkan tenaga kerja asing untuk mencari pekerjaan di Indonesia, hal-hal yang terkait dengan wawasan internasional sangat diperlukan oleh kepolisian, termasuk dalam tugas-tugas kepolisian tingkat daerah.

Namun, dalam pengamatan peneliti, kurikulum Bintara Polri tersebut belum menyertakan ASEAN sebagai satu mata pelajaran atau materi pokok yang diberi tempat khusus. Dalam wawancara peneliti dengan pihak kepolisian, hal ini juga ditegaskan oleh Kapolsek Purwokerto Utara Elvis Tellu, Kepala Bagian Sumber Daya Polres Purwokerto Yuliono Haryanto, dan Staf Pengajar Sekolah Polisi Negara (SPN) Purwokerto Sinaga. Kepolisian di tingkat sektor tidak mempelajari mengenai ASEAN karena jarang berhubungan dengan orang asing (Elvis Tellu, 2017; Yuliono Haryanto, 2017). SPN sendiri juga tidak mengajarkan mengenai ASEAN (Sinaga, 2017). Padahal, seperti yang akan penulis paparkan dalam bagian selanjutnya, perkembangan yang terjadi di kawasan Asia Tenggara, yang kemudian mempengaruhi situasi masyarakat dalam negeri, memperlihatkan bahwa wawasan dan pengetahuan mengenai ASEAN semakin penting bagi para penegak hukum seperti kepolisian. Lingkup cukup luas dalam 
kurikulum Bintara Polri merupakan potensi yang bisa diandalkan untuk memasukkan mata pelajaran ASEAN dalam kurikulum tersebut.

Masyarakat ASEAN Dan Peran Polisi Dalam Kejahatan Lintas Batas Negara Di Asia Tenggara

Pada bagian ini, peneliti mengamati setidaknya dua perkembangan regional yang membuat kepolisian perlu merumuskan ASEAN sebagai salah satu studi yang mesti dipelajari dalam kurikulum Bintara Polri. Dua perkembangan tersebut adalah kesepakatan ASEAN untuk membangun Komunitas ASEAN dan kejahatan transnasionalisme di kawasan. Keduanya membawa implikasi penting bagi pemahaman polisi mengenai ASEAN.

Pertama, kesepakatan ASEAN untuk membangun Komunitas ASEAN, yang terdiri dari tiga pilar, yaitu Pilar Politik dan Keamanan, Pilar Ekonomi, dan Pilar Sosial dan Budaya. Awalnya ASEAN didirikan pada tahun 1967 dengan harapan organisasi regional yang baru ini akan mampu menyelesaikan masalah bersama tanpa cara-cara kekerasan. Dengan kata lain, ASEAN memikirkan mengenai masalah keamanan kawasan. Pada tahap selanjutnya, negara-negara ASEAN mulai memikirkan mengenai integrasi ekonomi. Pada tahun 2003, dalam KTT ke-9 ASEAN di Bali, negara-negara anggota menyetujui pembentukan Komunitas ASEAN, yang di antaranya menyebutkan bahwa Komunitas Ekonomi ASEAN menargetkan integrasi ekonomi pada tahun 2020 dan dipercepat pada tahun 2015. Tidak cukup sampai di situ, dalam Komunitas ASEAN 2015, ada dua kata kunci penting dalam pengembangan integrasi intraASEAN ini, yaitu menciptakan rasa we feeling terhadap ASEAN dan mengubah citra ASEAN dari organisasi elitis menjadi organisasi yang bertumpu pada masyarakat atau peoplecentered organization (Haryanto \& Pasha, 2016: 253). Hal itu diikuti dengan kebijakankebijakan untuk mempermudah perpindahan manusia dari satu negara ke negara lain, seperti melalui liberalisasi transportasi dan jasa.

Implikasi dalamnegeri dari perkembangan kawasan itu adalah berdirinya Sekretariat Nasional ASEAN pada masa pemerintahan Presiden Susilo Bambang Yudhoyono melalui Keputusan Presiden No. 23 Tahun 2012 tentang Susunan Keanggotaan Sekretariat Nasional Association of Southeast Asian Nations (ASEAN)-Indonesia, yang kemudian ditindaklanjuti dengan Peraturan Menteri Luar Negeri No. 02 Tahun 2014 tentang Organisasi dan Tata Kerja Setnas ASEANIndonesia. Laman Sekretariat Nasional ASEAN dalam setnas-asean.id menyebutkan bahwa organisasi tersebut memiliki tugas dan fungsi yang terkait dengan Komunitas ASEAN, seperti memajukan identitas dan kesadaran ASEAN pada tingkat nasional dan berkontribusi pada pembentukan Komunitas ASEAN. Kepolisian merupakan salah lembaga yang menjadi anggpta Sekretariat Nasional ASEAN tersebut.

Kementrian Luar Negeri Indonesia pun turut menggarisbawahi pentingnya ASEAN dengan menawarkan mata kuliah ASEAN kepada Pusat Studi ASEAN di universitasuniversitas seluruh Indonesia. Matriks mata kuliah ASEAN yang ditawarkan oleh Kemenlu ditunjukkan dalam tabel 2.

Kedua, kejahatan transnasionalisme yang dilakukan oleh aktor transnasional. Mengutip Keohane \& Nye (1972) dan Morse (1972), Felsen \& Kalaitzidis (2005) menjelaskan bahwa aktor transnasional adalah aktor yang terlibat dalam aktivitas lintas batas 
Tabel 2

Matriks Mata Kuliah ASEAN

\begin{tabular}{|c|c|c|}
\hline No. & Topik & Materi Pokok \\
\hline 1. & Development of ASEAN & $\begin{array}{l}\text { Geo-politic situation of the region during ASEAN inception; } \\
\text { ZOPFAN and TAC; From loose integration to ASEAN Charter; } \\
\text { ASEAN Community; ASEAN vis a vis Europian Union key } \\
\text { characteristics and differences }\end{array}$ \\
\hline 2. & $\begin{array}{l}\text { Principles and Decision Mak- } \\
\text { ing Process }\end{array}$ & $\begin{array}{l}\text { Non-intervention; Peaceful resolution of disputes; Consen- } \\
\text { sus (Pro and Cons of Consensus, SEANWFZ and Consensus; } \\
\text { ASEAN-X Formula; Way Forward) }\end{array}$ \\
\hline 3. & $\begin{array}{l}\text { ASEAN Political-Security } \\
\text { Cooperation }\end{array}$ & $\begin{array}{l}\text { Key Aspect of APSC; Managing Conflict in ASEAN; Regional } \\
\text { Security Architecture (EAS \& ARF) }\end{array}$ \\
\hline 4. & $\begin{array}{l}\text { From AFTA to ASEAN Eco- } \\
\text { nomic Community }\end{array}$ & $\begin{array}{l}\text { Development of regional economic cooperation; Benefit and } \\
\text { challenges; AFTA's with Dialogue Partners }\end{array}$ \\
\hline 5. & Socio-Cultural Cooperation & $\begin{array}{l}\text { Why cultural identity is important; Key aspects of Socio-Cultural } \\
\text { Cooperation; Managing balance cooperation with two other pil- } \\
\text { lars }\end{array}$ \\
\hline 6. & Simulasi Sidang ASEAN & \\
\hline 7. & $\begin{array}{l}\text { ASEAN and Dialogue Part- } \\
\text { ners }\end{array}$ & Why ASEAN?; Type of Cooperation; ASEAN Centrality \\
\hline 8. & $\begin{array}{l}\text { Regional Comprehensive } \\
\text { Economic Partnership }\end{array}$ & $\begin{array}{l}\text { Connecting AFTA's; Status of negotiation; Creating balance and } \\
\text { fair trade; Managing different interest }\end{array}$ \\
\hline 9. & Human Rights and ASEAN & $\begin{array}{l}\text { Development of human rights cooperation in ASEAN; AICHR: } \\
\text { Achievement and Shortcomings; Future Direction of Human } \\
\text { Rights Cooperation in ASEAN }\end{array}$ \\
\hline 10. & $\begin{array}{l}\text { ASEAN and Sub Regional } \\
\text { Cooperation }\end{array}$ & $\begin{array}{l}\text { Introduction to BIMP-EAGA, IMTG, and Mekong River Coop- } \\
\text { eration; Oyher sub regional cooperation; Trilateral Cooperation } \\
\text { on Marawi, Maritime Patrol and Other; Subregional and ASE- } \\
\text { AN: Reinforcing ot Competition }\end{array}$ \\
\hline
\end{tabular}

Sumber: Kementrian Luar Negeri Republik Indonesia, 2017

negara, seperti perpindahan uang, informasi, maupun manusia. Dalam aktivitasnya, aktor transnasional sangat mungkin menjalankan perilaku yang berlawanan dengan kepentingan negara mereka sendiri melalui kejahatankejahatan transnasional. Menurut Bossard (1990), kejahatan transnasionalisme adalah an activity that is considered a criminal offense by at least two countries. Masih menurut Bossard, kejahatan transnasionalisme yang semakin berkembangmerupakan efek yang ditimbulkan dari kemajuan yang ada, seperti kemajuan transportasi dan telekomunikasi. Kemajuan yang diharapkan untuk menghasilkan kemakmuran, kebebasan, dan keamanan, ternyata juga memiliki potensi negatif dengan menghasilkan perpecahan sosial, kekerasan, dan konflik. Dengan kata lain, globalisasi memiliki peran dalam menumbuhkan kejahatan transnasionaslisme (Viano, 2009: 66).

Dari situ peneliti memahami kejahatan transnasionalisme merupakan ancaman terhadap keamanan masyarakat yang berada pada lingkup lintas batas negara. Masalah yang sering menjadi rujukan akar terorisme dalam lintas batas negara, misalnya, adalah hegemoni Barat yang dianggap menindas negara-negara Islam di Timur Tengah, yang kemudian pikiran tersebut menjalar membentuk jaringan teroris di Indonesia (Purwawidiada, 2014: 3). Dalam perspektif inilah penulis melihat ancaman kejahatan transnasional terhadap suatu masyarakat atau komunitas. Karena sifat kejahatan yang melintasi batas negara, maka kerja sama dalam level regional sangat 
diperlukan untuk mengatasi persoalan tersebut. Dalam dokumen ASEAN Plan of Action to Combat Transnational Crimes (ASEAN PACTC) yang merupakan hasil konvensi kejahatan transnasional tahun 2002, ASEAN sendiri menyebutkan delapan jeniskejahatan lintas negara yang berusaha ditangani bersama-bersama, yaitu perdagangan gelap narkoba, perdagangan manusia, pembajakan di lautan,penyelundupan senjata, pencucian uang, terorisme, kejahatan ekonomi internasional, dan kejahatan internet. Beberapa isu tersebut, seperti narkoba dan terorisme yang telah dipaparkan di atas, telah masuk dalam materi mata pelajaran Bintara Polri.

Implikasi dari pemahaman itu adalah pembentukan ASEAN National Police (ASEANAPOL) pada tahun 1981 oleh lima negara anggota ASEAN, yaitu Indonesia, Malaysia, Filipina, Singapura, dan Thailand. Setelah lima negara pendiri, negara-negara Asia Tenggara lainnya kemudian menyusul bergabung dengan konferensi ASEANAPOL seiring masuknya negara-negara tersebut menjadi anggota ASEAN. Kepolisian Brunei Darussalam bergabung dalam konferensi tahunan ASEANAPOL pada tahun 1984 di Kuala Lumpur, Malaysia. Kepolisian Vietnam bergabung pada tahun 1996, diikuti Laos dan Myanmar pada tahun 1998 saat konferensi berlangsung di Brunei Darussalam, lalu kemudian Kamboja pada tahun 2000 saat konferensi di Yangon, Myanmar. Sejak tahun 1981, ASEANAPOL selalu mengadakan konferensi tahunan.

Meskipun telah terbentuk sejak tahun 1981, ASEANAPOL baru mulai mempertimbangkan untuk memiliki kantor sekretariat yang permanen pada tahun 2005. Pada tahun 2008, kepolisian negara-negara ASEAN menyetujui untuk membuat kantor
Sekretariat ASEANAPOL di Kuala Lumpur, Malaysia. Sekretariat ASEANAPOL akhirnya mulai beroperasi pada tahun 2010. Menurut situs resmi ASEANAPOL, pembentukan sekretariat permanen memiliki setidaknya empat tujuan utama, yaitu (1). Untuk menyelaraskan dan melakukan standarisasi mekanisme koordinasi dan komunikasi antara lembaga kepolisian ASEAN. (2). Untuk melakukan studi yang komprehensif dan integratif mengenai resolusi yang disepakai dalam komunike bersama. (3). Untuk membangun mekanisme yang bertanggung jawab dalam memantau dan menindaklanjuti pelaksanaan resolusi dalam komunike bersama. (4). Untuk mengubah resolusi yang diadopsi dalam komunike bersama menjadi rencana aksi dan program kerja ASEANAPOL.

Dengan adanya ASEANAPOL, kepolisian Indonesia sebenarnya telah berusaha terlibat dalam isu-isu kejahatan transnasional, setidaknya dalam lingkup kawasan Asia Tenggara. Keterlibatan ini sangat penting karena persoalan yang berkembang di dalam negeri, seperti kasus perdagangan gelap dan penyebaran narkoba serta terorisme, merupakan masalah yang tidak hanya berakar di dalam negeri, tetapi juga bisa dari luar kawasan. Kepolisian Indonesia, misalnya, memiliki kepentingan untuk mengetahui perkembangan kawasan produksi terbesar narkoba yang berada di Segitiga Emas dan bagaimana jalur-jalur penyelundupan baru dari kepolisian negara lain. Kepolisian Indonesia juga perlu mengetahui atau memberikan informasi mengenai jalur-jalur masuknya teroris, bagaimana perkembangan terorisme di Indonesia, serta bagaimana langkah-langkah yang telah dilakukan Polri dalam menangani hal itu. Pada gilirannya, ASEANAPOL merupakan keterlibatan yang positif dari Polri 
untuk menertibkan dan mengamankan situas masyarakat dalam negeri.

\section{Kurikulum ASEAN Sebagai Pendorong Kualitas Dan Efektivitas Kerja Kepolisian}

Pada bagian ini, peneliti berusaha mengamati bagaimana strategi Indonesia dalam mewujudkan keamanan regional. Dalam ASEAN, Indonesia memiliki peran yang cukup besar dalam merumuskan konsepsi ganda mengenai ketahanan nasional dan ketahanan regional. Menteri Luar Negeri Indonesia Adam Malik mengajukan konsepsi ganda tersebut sejak Sidang Tahunan Menteri Luar Negeri di Singapura pada tahun 1972 (Haryanto \& Pasha, 2016: 218-219). Gagasan ketahanan nasional menurut Lembaga Ketahanan Nasional adalah kondisi dinamis suatu bangsa yang mampu mengembangkan kekuatan secara nasional untuk menghadapi segala tantangan, ancaman, hambatan, serta gangguan yang datang dari dalam maupun dari luar yang langsung maupun tidak langsung membahayakan identitas, integritas, dan kelangsungan hidup bangsa (Lemhannas, 1997).

Lebih lanjut, ketahanan regional, menurut Brigjen Haryomataram, merupakan keuletan dan daya tahan suatu kawasan tersebut untuk mengatasi atau menanggulangi segala ancaman, baik yang datang dari dalam, maupun dari luar kawasan, yang langsung ataupun tidak langsung membahayakan kelangsungan hidup negara-negara dan bangsa-bangsa yang hidup dalam kawasan tersebut (Departemen Luar Negeri, 1998: 193-195). Rumusan itulah yang kemudian masuk dalam Treaty of Amity and Cooperation (TAC), terutama ayat 11 dan 12, yang ditandatangani lima pemimpin pendiri ASEAN pada tahun 1976. Ayat 11 berbunyi The High Contracting Parties shall endeavour to strengthen their respective national resilience in their political, economic, socio-cultural as well as security fields in conformity with their respective ideals and aspirations, free from external interference as well as internal subversive activities in order to preserve their respective national identities. Sementara ayat 12 menyatakan bahwa: The High Contracting Parties in their efforts to achieve regional prosperity and security, shall endeavor to cooperate in all fields for the promotion of regional resilience, based on the principles of self-confidence, self-reliance, mutual respect, cooperation and solidarity which will constitute the foundation for a strong and viable community of nations in Southeast Asia (Sekretariat ASEAN 1976).

Polri sendiri telah memiliki dasar hukum untuk berpartisipasi mewujudkan ketahanan regional yang diperjuangkan oleh diplomat Indonesia tersebut. Undang-Undang Nomor 2 Tahun 2002 tentang Kepolisian Republik Indonesia pasal 15 poin 2 ayat $\mathrm{h}$ menyatakan bahwa kepolisian memiliki wewenang untuk melakukan kerja sama dengan kepolisian negara lain dalam menyidik dan memberantas kejahatan internasional. Dalam poin penjelasan, kejahatan internasional yang dimaksud pada ayat tersebut adalah kejahatankejahatan tertentu yang disepakati untuk ditanggulangi antarnegara, seperti kejahatan narkotika, peredaran uang palsu, isu terorisme, serta kasus perdagangan manusia.

Pada pasal 15 ayat j, Kepolisian Republik Indonesia memiliki wewenang untuk mewakili pemerintah Republik Indonesia dalam organisasi kepolisian internasional. Dalam poin penjelasan pasal, Kepolisian Negara Republik Indonesia terikat oleh ketentuan hukum internasional, baik perjanjian bilateral maupun perjanjian multilateral. 
Dalam hubungan tersebut Kepolisian Negara Republik Indonesia dapat memberikan bantuan untuk melakukan tindakan kepolisian atas permintaan dari negara lain sebaliknya Kepolisian Negara Republik Indonesia dapat meminta bantuan untuk melakukan tindakan kepolisian dari negara lain sepanjang tidak bertentangan dengan ketentuan hukum dari kedua Negara.

Oleh karena itu, tantangan untuk polisi dalam masyarakat yang semakin cair dan mudah melintasi batas negara adalah menemukan paradigma baru dalam menjaga ketertiban. Salah satu paradigma lama, misalnya, mementingkan tatanan untuk menempatkan satu etnis tertentu dalam satu geografis dan wilayah sosial tertentu (McDonald, 2003: 234). Paradigma baru yang dimaksud di sini adalah menempatkan integrasi, toleransi, serta penghargaan yang sama sebagai dasar untuk menjaga ketertiban di masyarakat. Pada era globalisasi, perubahan demografi kemungkinan bisa berubah di seluruh dunia. Akibat adanya imigrasi, masyarakat di suatu negara tidak hanya ditinggali oleh masyarakat dari satu negara saja, melainkan warga negara lain yang dengan berbagai kepentingan tinggal di negara tersebut. Pasca Perang Dingin berakhir, batasbatas internasional menjadi semakin pudar (Schmid, 1996).

Paradigma baru itu tidak hanya memudahkan adanya migrasi, namun juga menimbulkan efek negatif akibat perindahan manusia. Memang masih ada masalah dalam isu toleransi dan hak asasi manusia, misalnya, mengenai pengungsi dan pencari suaka. Pengungsi dan pencari suaka biasanya berasal dari daerah Timur Tengah atau Asia Selatan, dan juga Myanmar, yang tengah melintasi menuju Australia. Dalam perlintasan tersebut,
Indonesia merupakan negara yang memiliki letak strategis, yaitu sebagai penghubung dalam jalur pelayaran. Para pengungsi dan pencari suaka yang terdampar di Indonesia atau gagal menyebrang menuju Australia dianggap menyulitkan pemerintah. Di satu sisi, Indonesia bukan negara maju yang memiliki anggaran besar untuk hal-hal semacam itu. Indonesia juga bukan merupakan anggota Konvensi Pengungsi PBB. Namun, di sisi lain, pengungsi dan pencari suaka merupakan manusia yang harus dihormati hak asasinya, terutama hak asasi untuk hidup. Indonesia sebagai negara harus bersikap. Jika pengungsi tersebut diterima dan hidup di tengah masyarakat Indonesia, kepolisian yang memiliki tugas untuk menjaga ketertiban dan keamanan lingkungan harus mampu mengemban tugas tersebut di tengah masyarakat yang berkomunikasi dalam beragam bahasa.

Dengan memahami persoalan yang ada, mata pelajaran ASEAN mampu menjadi pendorong kualitas dan efektivitas kerja kepolisian, baik pusat maupun daerah. Beberapa persoalan yang muncul di masyarakat menjadi pertimbangan kuat di sini adalah sebagai berikut.

Pertama, kejahatan transnasional berupa peredaran narkoba di kalangan masyarakat daerah merupakan satu bagian dari kejahatan perdagangan narkoba lintas negara.

Kedua, kemudahan jalur transportasi di masa depan dimana mobil-mobil dengan plat Thailand atau Malaysia bebas melaju di seluruh wilayah Indonesia. Hal ini akan menjadi masalah jika warga negara asing yang mengendari mobil berplat Thailand atau Malaysia tidak memahami aturan lalu lintas di Indonesia. Kepolisian adalah garda depan untuk memberikan pemahaman dan menjaga ketertiban di masyarakat. Di sisi lain, mungkin juga warga lokal atau warga 
negara asing tidak tahu bagaimana cara melaporkan suatu tindakan kriminal, apalagi yang berkaitan dengan budaya warga negara lain. Budaya atau kultur negara lain sangat mungkin menjadi masalah. McDonald (2003: 239) mencontohkan perbedaan dari berbagai komunitas yang bisa menjadi masalah di Amerika Serikat. Di antara masalah tersebut, misalnya, para pengungsi dari Vietnam tidak memahami bahwa mereka tidak boleh memancing di danau setempat tanpa lisensi, imigran dari El Salvador merasa tidak masalah kencing di trotoar, imigran dari Timur Tengah merasa tidak ada masalah menikahkan perempuan di usia yang sangat muda, atau imigran dari negara lain yang tidak bisa membaca tanda lalu lintas.

Ketiga, imigran ilegal. Dengan kemudahan transportasi, bukan tidak mungkin warga negara lain mudah untuk berpindah tempat ke negara tujuan.

Keempat, perlindungan warga luar negeri dari serangan xenofobia (ketidaksukaan atau ketakutan terhadap orang-orang dari negara lain) sesuai dengan tugas polisi untuk melindungi masyarakat.

Meskipun kepolisian yang berada di kota-kota menengah atau kota-kota kecil belum banyak berurusan dengan warga negara asing, ke depan hal itu sangat mungkin berubah, terutama jika daerah tersebut berencana membangun bandara seperti dalam kasus Purwokerto (Haryanto dan Pasha, 2016). Perpindahan manusia dari luar negeri ke daerah-daerah di Indonesia menjadi semakin mudah. Untuk mempersiapkan diri dengan perkembangan-perkembangan regional dan kebijakan-kebijakan yang berimbas pada masyarakat, kepolisian di tingkat pusat perlu mempertimbangkan untuk menambah wawasan mengenai ASEAN dengan memasukkan mata pelajaran ASEAN dalam kurikulum Bintara Polri. Sesuai dengan hasil wawancara dengan Elvis Tellu (2017) dan Sinaga (2017), kebijakan kurikulum merupakan kewenangan Markas Besar Polri.

\section{SIMPULAN}

Berdasar penjelasan tersebut diatas dapat ditarik simpulan sebagai berikut.

Pertama, Kepolisian RI adalah alat negara yang berperan dan bertugas dalam memelihara keamanan dan ketertiban masyarakat, menegakkan hukum, dan memberikan perlindungan, pengayoman, dan pelayanan kepada masyarakat demi keamanan dalam negeri. Namun, keamanan dalam negeri saat ini semakin berkaitan dengan situasi internasional.

Kedua, terdapat 2 (dua) situasi internasional yang mempengaruhi masyarakat Indonesia, yaitu perkembangan ASEAN menjadi Komunitas ASEAN yang ingin menciptakan masyarakat ASEAN, serta ancaman kejahatan transnasionalisme yang beroperasi dalam lintas batas negara. Untuk menjaga ketertiban dan memberikan perlindungan bagi masyarakat dalam dua perkembangan situasi tersebut, kepolisian membutuhkan wawasan dan pengetahuan ASEAN.

Ketiga, selama ini kurikulum Bintara Polri belum menyentuh mengenai persoalan ASEAN. Materi-materi yang berkaitan dengan hubungan internasional adalah HAM dan terorisme. Padahal, bintara merupakan garda terdepan dalam menjaga ketertiban dan menjadi pengayom bagi masyarakat Indonesia. Dengan demikian, dalam menghadapi masyarakat heterogen di masa mendatang, mata pelajaran mengenai ASEAN perlu masuk dalam kurikulum Bintara Polri. 


\section{DAFTAR PUSTAKA}

Alpert, G.P. \& Piquero, A. R. (eds.) 2000, Community Policing: Contemporary Readings, Porspect Heights, IL: Waveland Press.

Anggoro, K. 2003, 'Transnational Security Concerns Defence Modernization and Security Cooperation in Southeast Asia', Dialogue + Cooperation, 25-28

ASEAN 2017, 'ASEAN Plan of Action in Combating Transnational Crime (20162025), diakses dari http://asean.org/ storage/2012/05/ASEAN-Plan-of-Actionin-Combating-TC_Adopted-by-11thAMMTC-on-20Sept17.pdf.

Bittner, E. 1970, The Functions of the Police in Modern Society: A Review of Background Factors, Current Practices, and Possible Role Models, Maryland: National Institute of Mental Health, Center for Studies of Crime and Delinquency.

Badan Narkotika Nasional, 2013, 'Muzammil: Presiden SBY Seharusnya Pimpin Langsung Pemberantasan Narkoba', diakses dari http://www.bnn.go.id/read/berita/11309/ muzammil-presiden-sby-seharusnyapimpin-langsung-pemberan tasan-narkoba.

Caballero-Anthony, M. 2006, 'Understanding the Dynamics of Securitizing NonTraditional Security'. Dalam CaballeroAnthony, M., Emmers, R., \& Acharya, A. (eds.), Non-Traditional Security in Asia: Dilemmas in Securitisation (h. 1-14), London: Ashgate Publishers. , 2010. 'Non-

Traditional Security Challenges, Regional Governance, and the ASEAN PoliticalSecurity Community (APSC)', Working Paper No. 7, Singapore: Nanyang Technological University.
Creswell, J. W. 2010, Research Design: Pendekatan Kualitatif, Kuantitatif, dan Mixed, Yogyakarta: Pustaka Pelajar.

Danendra, I. B. K. 2012, 'Kedudukan dan Fungsi Kepolisian dalam Struktur Organisasi Negara Republik Indonesia', Lex Crimen, 1(4), 41-59.

Departemen Luar Negeri 1998, Sejarah Diplomasi Republik Indonesia dari Masa ke Masa: Buku IV A Periode 1966-1995 (Masa Orde Baru), Jakarta: Penulis.

Emmers, R. 2007,'International RegimeBuilding in ASEAN: Cooperation againts the Illicit Trafficking and Abuse of Drugs', Contemporary Southeast Asia, 29(3), 506-525.

Felsen, D. \& Kalaitzidis, A. 2005, 'A Historical Overview of Transnational Crime'. Dalam Handbook of Transnational Crime \& Justice (h. 3-19), Sage: Thousand Oaks, CA.

Fischer, J. 2008, 'Disease Respects no Borders: Governance, the State, and Regional Healts Security'. Dalam Pandya, A. \& Laipson, E., Transnational Trends: Middle Eastern and Asian Views, Washington, DC: The Henry L. Stimson Centre.

Haryanto, A. \& Pasha, I 2016, Diplomasi Indonesia: Realitas dan Prospek, Yogyakarta: Pustaka Ilmu.

Hediarto, I., Armawi, A., \& Martono, E. 2016, 'Optimalisasi Peran KODIM dalam Penanganan Tanggap Darurat Bencana Alam dan Implikasinya terhadap Ketahanan Wilayah (Studi di KODIM 0613/ Ciamis, Jawa Barat) ', Jurnal Ketahanan Nasional, 22(3), 321-333.

Human Right Wacth, 2017, World Report 2017: Indonesia Events of 2016, New York. 
Ibarra, P. R. 2003, Contacts with the Police: Patterns and Meanings in a Multicultural Realm. Dalam Community \& Civil Guard Department Israel National Police, 'Policing a Multicultural Society',Journal of Police \& Society, No. 7, 133-164.

Kementerian Luar Negeri, 2017, Draft Kurikulum ASEAN, Jakarta, Pusat Studi ASEAN Kementerian Luar Negeri.

Kunarto, 1997, Etika Kepolisian, Jakarta: Cipta Manunggal.

Latif, A. \& Agustan 2017, 'Karakteristik Data Geospasial sebagai Dasar Perencanaan untuk Memperkuat Ketahanan Perbatasan NKRI (Studi tentang Perencanaan Kota Perbatasan Distrik Sota, Merauke, Provinsi Papua dengan Papua Nugini)', Jurnal Ketahanan Nasional, 23(3), 263-279.

Lembaga Pendidikan dan Pelatihan Mabes Kepolisian Negara Republik

Indonesia, 2017, Kurikulum Bintara Polri Tugas Umum, Jakarta, Mabes Kepolisian Negara Republik Indonesia.

Lemhannas, 1997, Ketahanan Nasional, Jakarta, Balai Pustaka

Marshall, A. R.C. 2016, 'Mekong Nations Take on Golden Triangle Narco-Empire', diakses dari http://www.maritimeexecutive.com/features/mekong-nationstake-on-golden-triangle-narco-empire.

Merianingrum, D. 2014, Peranan Kemitraan Polisi Republik Indonesia dalam Memelihara Stabilitas Keamanan dan Ketertiban Masyarakat, Ponorogo, Universitas Muhammadiyah

McDonald, W. F. 2003, The Emerging Paradigm for Policing Multiethnic Societies: Glimpses from the American Experience. Dalam Community \& Civil
Guard Department Israel National Police, 'Policing a Multicultural Society',Journal of Police \& Society, No. 7, 231-253.

Police Executive Research Forum 2014, Future Trends in Policing, Washington, D.C.: Office of Community Oriented Policing Services.

Purwawidada, F. 2014, 'Jaringan Teroris Solo dan Implikasinya terhadap Keamanan Wilayah serta Strategi Penanggulangannya (Studi di Wilayah Solo, Jawa Tengah)', Jurnal Ketahanan Nasional, 20(1), 1-11.

Pushpanathan, S. 1999, Managing Transnasional Crime in ASEAN, diakses dari http://asean.org/managingtransnational-crime-in-asean-by-spushpanathan/.

Rusdi, B. M. 2014, Peranan Kepolisian dalam Menanggulangi Tindak Pidana Pelaporan Palsu Kehilangan Sepeda Motor di Polres Lampung Selatan, Universitas Lampung. Schmid, A.P., 2016, Links Between Terrorism and Migration: An Exploration, The Hague: ICCT Research Paper.

Sekretariat ASEAN 1976, 1976 Treaty of Amity and Cooperation in Southeast Asia, Bali: Penulis.

Sekretariat Kabinet Republik Indonesia, 2015, Sambutan Presiden Joko Widodo Pada Peringatan Hari Anti Narkotika Internasional, Jakarta.

Southeast Asian Human Rights and Peace Studies Network, 2016, An Introduction to Human Rught in Southeast Asian: Volume 2, Thailand: Mahidol University.

Viano, E. C. 2009-2010, 'Globalization, Transnational Crime and State Power: The Need for a New Criminology',Rivista di 
Criminologia, Vittimologia e Sicurezza, 3(3)-4(1), 63-85.

\section{Peraturan Perundangan}

Undang-Undang Nomor 2 Tahun 2002 Tentang Polri

Undang-Undang Nomor 34 Tahun 2004 Tentang Tentara Nasional Indonesia

Keputusan Presiden No. 23 Tahun 2012 Tentang Susunan Keanggotaan Sekretariat Nasional Association of Southeast Asian Nations (ASEAN)-Indonesia.
Peraturan Menteri Luar Negeri No. 02 Tahun 2014 Tentang Organisasi dan Tata Kerja Setnas ASEAN-Indonesia.

Surat Keputusan Kepala Lembaga Pendidikan dan Pelatihan Polri Nomor Kep/ 252/V/2017 Tentang Pendidikan Pembentukan Bintara Polri Tugas Umum.

\section{Wawancara}

Sinaga, tanggal 7 Agustus 2017.

Elvis Tellu, tanggal 28 Agustus 2017.

Yuliono Haryanto, tanggal 12 September 2017. 